\title{
PENGINTEGRASIAN ILMU DI UNISMUH MAKASSAR
}

\author{
Sulaeman Masnan ${ }^{1}$, Wahdaniyah ${ }^{2}$ \\ ${ }^{*}$ Pendidikan Agama Islam Fakultas Agama Islam| Unismuh Makassar \\ ${ }^{* 2}$ Pendidikan Agama Islam Fakultas Agama Islam| Unismuh Makassar \\ ${ }^{* 1}$ sulaemanm@unismuh.ac.id
}

\begin{abstract}
ABSTRAK
Penelitian ini bertujuan mendeskripsikan dan menganalisis mengenai urgensi integrasi ilmu dan model pengintegrasian ilmu di Unismuh Makassar serta menganalisis faktor pendukung dan kendalanya. Penelitian ini adalah penelitian kualitatif dengan menggunakan observasi, wawancara, dan dokumentasi sebagai metode pengumpulan data. Teтuan penelitian ini menunjukkan bahwa integrasi ilmu keislaman dan sains merupakan bagian dari implementasi visi dan misi Unismuh Makassar sekaligus merupakan konsekuensi logis Unismuh sebagai perguruan tinggi berciri Islam. Model integrasi yang diterapkan di Unismuh Makassar belum ada yang baku, bahkan dapat dikatakan masih mencari model yang ideal. Pilihannnya, bisa islamisasi ilmu, ilmuisasi Islam, atau integrasi-interkoneksi. Integrasi ilmu di Unismuh Makassar didukung oleh kebijakan pimpinan yang pro pada program ini, selain iklim akademik yang cukup kondusif. Hanya saja masih terkendala pada minimnya kualitas sumber daya dosen yang mumpuni yang dapat mengintegrasikan agama dan sains.
\end{abstract}

Kata Kunci: Integrasi Ilmu, Ilmu Keislaman, Sains

\begin{abstract}
This study aims to describe and analyze the urgency of integration of science and model of integrating science in Makassar Muhammadiyah University and analyze the supporting factors and constraints. This research is a qualitative research using observation, interview, and documentation as data collection method. The findings of this study indicate that the integration of Islamic science and science is part of the implementation of vision and mission of Unismuh Makassar as well as a logical consequence of Makassar Muhammadiyah University as a college characterized by Islam. Integration model applied in Makassar Muhammadiyah University has not been standard, even can be said still looking for ideal model. Alternatively, it can be Islamization of science, Islamic illusion, or integration-interconnection. The integration of science in Makassar is supported by the pro-leadership policy in this program, in addition to a conducive academic climate. It's just still constrained by the lack of qualified lecturers qualified resources that can integrate religion and science.
\end{abstract}

Keywords: Integration Science, Islamic Science, Science 


\section{PENDAHULUAN}

Gagasan tentang integrasi ilmu agama (Islam) dan ilmu umum (sains modern) telah dikaji secara mendalam oleh sejumlah intelektual muslim. Beragam pendapat dan bentuk antusiasme muncul sebagai respons atas gagasan ini. Ada yang masih merumuskan dalam bentuk gagasan teoretik, sebagian yang lain telah melangkah lebih jauh dengan mempraktikkan gagasan ini pada institusi pendidikan Islam.

Gagasan integrasi sains dan Islam mendapat momentumnya di Indonesia ketika konversi beberapa Institut Agama Islam Negeri (IAIN) ke Universitas Islam Negeri (UIN). Semula IAIN hanya mengelola program studi ilmu agama bertransformasi menjadi UIN yang mengelola beragam program studi, termasuk progam studi ilmu sosialhumaniora serta sains dan teknologi. Transformasi dari IAIN ke UIN menandakan dimulainya aplikasi gagasan integrasi sains Islam dengan sains sekuler dalam universitas Islam.

Penelitian Anshori dan Zaenal Abidin (2014) mengungkapkan, minimal ada tiga tipologi relasi Islam dan sains modern yang diwacanakan para intelektual muslim, yaitu islamisasi ilmu pengetahuan (islamization of knowledge), pengilmuan Islam (scientification of Islam), dan integrasi-interkoneksi keilmuan. Namun dalam konteks UIN, semua menegaskan integrasi keilmuan sebagai pilihan paradigmanya dan menjadikan nilai Islam dalam alQur'an dan hadis sebagai dasar, meskipun dalam penerjemahannya ke dalam langkah-langkah operasional pendidikan tidak sepenuhnya sama.

Perkembangan paradigma keilmuan di perguruan tinggi Islam negeri dengan proses saling mendekatkan antardisiplin ilmu sejatinya juga sudah terjadi di perguruan tinggi Islam swasta. Dugaan sementara, sebagian perguruan tinggi swasta yang lahir dari organisasi Islam dengan keunikan masing-masing dapat menerima perkembangan integrasi ilmu sebagaimana di UIN. Sejauh ini sudah ada upaya-upaya kreatif dari perguruan tinggi Islam swasta, seperti Universitas Muhammadiyah (Unismuh) Makassar untuk memadukan disiplin ilmu yang kemudian diterjemahkan ke dalam kurikulum dan proses pembelajaran.

Unismuh Makassar menjadi salah satu universitas Islam swasta yang bercita-cita mengintegrasikan ilmu dan agama, sebagaimana tercermin dalam Statuta Unismuh bab III pasal 7 ayat 1 dan 2, bahwa Unismuh merupakan perguruan tinggi yang berasaskan Islam, berfungsi sebagai pencetak akademisi yang berjiwa tauhid sebagai pemandu dan pencerah kepada seluruh lapisan dalam kehidupan bermasyarakat (Unismuh, 2001). Hal ini sejalan dengan obsesi K.H. Ahmad Dahlan (pendiri Muhammadiyah) sebagaimana dikutip Hamdan (2009), yaitu agar lembaga 
pendidikan Muhammadiyah dapat melahirkan manusia baru yang mampu tampil sebagai ulama-intelek atau intelek-ulama, yaitu seorang muslim yang memiliki keteguhan iman dan ilmu yang luas. Penyatuan itu tidak sekadar menyatuatapkan kedua ilmu itu dalam satu institusi, tetapi menjadikannya satu entitas yang tunggal dan tidak terpisah. Artinya, di lingkungan perguruan tinggi Muhammadiyah (PTM), khususnya Unismuh Makassar perlu melakukan penyusunan epistemologi keilmuan yang lebih kokoh dan visioner ketimbang hanya menyandingkan ilmu umum dan ilmu agama dalam kurikulum.

Konteks inilah yang melatarbelakangi pentingnya penelitian ini dengan mengambil fokus pada: (1)Bagaimana urgensi pengintegrasian ilmu agama dan sains modern di Unismuh Makassar? (2) Bagaimana model pengintegrasian-nya? (3) Apa yang menjadi pendukung dan kendala dalam pengintegrasian ilmu agama dan sains modern di Unismuh Makassar?

\section{METODE PENELITIAN}

Penelitian ini berlokasi di Unismuh Makassar yang terletak di Jalan Sultan Alauddin No. 259 Kota Makassar. Ada tiga prodi yang dijadikan lokus utama penelitian ini, yaitu Prodi Ekonomi Islam pada Fakultas Ekonomi dan Bisnis, Prodi Hukum Ekonomi Islam pada Fakultas Agama Islam, dan Prodi Pendidikan Dokter pada Fakultas Kedokteran.
Ketiga prodi ini memiliki program pengintegrasian ilmu, baik dalam kurikulum, materi maupun aktivitas perkuliahannya.

Jenis penelitian ini adalah penelitian kualitatif deskriptif yang bermaksud memahami paradigma integrasi keilmuan yang dipahami dan dikembangkan oleh civitas akademika di Unismuh Makassar.

Data diperoleh melalui observasi dan wawancara terhadap pimpinan dan dosen di Unismuh Makassar. Selain itu, data juga diperoleh melalui kajian dokumen, buku, majalah, dan referensi lain yang dianggap relevan. Teknik pengolahan dan analisis data dalam penelitian ini menggunakan model interaktif yang dikemukakan oleh Miles dan Huberman, sebagaimana dikutip Sugiyono (2011: 246), yaitu dimulai dengan reduksi data, penyajian data, dan penarikan kesimpulan/verifikasi.

\section{HASIL PENELITIAN DAN PEMBAHASAN}

1. Urgensi Integrasi Ilmu Agama dan Sains Modern di Unismuh Makassar Observasi yang dilakukan peneliti menemukan bahwa integrasi ilmu agama (Islam) dan ilmu umum (sains modern) di Unismuh Makassar bukan lagi sekadar wacana, tetapi telah menjadi program nyata. Ada tiga program studi yang nomenklatur, visi misi, dan kurikulumnya telah mengintegrasikan Islam dan sains modern. Ketiga program studi itu adalah (1) Prodi Ekonomi Islam pada 
Fakultas Ekonomi dan Bisnis; (2) Prodi Hukum Ekonomi Islam pada Fakultas Agama Islam; dan (3) Prodi Pendidikan Dokter pada Fakultas Kedokteran, khusus untuk Prodi Pendidikan Dokter meskipun tidak secara eksplisit mencantumkan nama Islam pada nomenklatur prodinya, tetapi visi dan kurikulumnya didisain untuk mengintegrasikan Islam dan ilmu kedokteran.

Ketika berbicara tentang integrasi keilmuan di Unismuh Makassar, maka dosen dan civitas akademika pada tiga prodi tersebutlah yang dianggap tepat dan representatif untuk dielaborasi pandangannya. Dari penelitian yang dilakukan tampak bahwa dosen pada tiga prodi tersebut memiliki kesamaan pandangan, terutama pada soal urgensi integrasi keilmuan di Unismuh Makassar. Mereka berpendapat bahwa integrasi keilmuan sudah menjadi keharusan bagi sebuah perguruan tinggi yang memiliki ciri khas Islam, seperti Unismuh Makassar. Samsul Risal (dosen Fak. Ekonomi dan Bisnis, menjelaskan bahwa: integrasi ilmu keislaman dan sains di Fakultas Ekonomi dan Bisnis sangat penting, karena ini selaras dengan misi dan tujuan Fakultas Ekonomi dan Bisnis. Apalagi dengan adanya prodi Ekonomi Islam yang menunjukkan bahwa kita ingin mengembangkan disiplin ilmu ekonomi yang bersumber dari ajaran Islam, yaitu al-Qur'an dan al-Sunnah. Jadi, pengintegrasian ilmu keislaman dan sains itu harus dilakukan.
Samsul Rizal memandang integrasi ilmu keislaman dan sains sebagai bagian dari perwujudan misi dan tujuan Fakultas Ekonomi dan Bisnis. Misi yang dimaksud adalah (1) Menyelenggarakan pendidikan dan pengajaran yang dilandasi nilai keislaman, dan diarahkan sesuai dengan kebutuhan (stakeholder). (2) Menyelenggarakan pendidikan berdasarkan al-Islam Kemuhammadiyahan. Adapun tujuannya adalah menghasilkan sarjana ekonomi muslim yang beriman, bertakwa, dan berakhlak mulia.

Misi dan tujuan Fakultas Ekonomi dan Bisnis menunjukkan bahwa dalam pelaksanaan pendidikan memiliki dua misi utama yaitu pembinaan daya intelektual dan pembinaan daya moral yang bersumber dari ajaran Islam. Oleh karena itu, mensinergikan sains dan Islam merupakan keniscayaan. Jika mengabaikan nilai-nilai Islam dalam perkembangan sains dan teknologi akan melahirkan dampak negatif, tidak hanya pada tatanan sosialkemanusiaan, tetapi juga pada orde kosmos atau alam semesta ini. Dampak negatif dari kecendurungan mengabaikan nilai-nilai moral agama dapat dilihat secara emperik pada perilaku korup, manipulatif, dan lain sebagainya. Ilmu ekonomi semakin maju, tetapi realitas kehidupan semakin timpang, yang kaya semakin kaya dan yang miskin tetap dalam kemiskinannya. 
Urgensi pengintegrasian ilmu keislaman dan sains juga dikemukakan oleh Irwan Ashari (Dosen Fakultas Kedokteran). Ia menilai sangat penting karena sejalan dengan tujuan Fakultas Kedokteran Unismuh, yaitu menghasilkan dokter yang berwawasan keislaman; dokter yang alim, saleh, dan profesional.

Pendapat yang senada dengan di atas dikemukakan oleh Muhlis Mappangaja (Ketua Prodi Hukum Ekonomi Islam). Ia memandang urgensi integrasi ilmu keislaman dan ilmu umum juga dari sudut pandang kesesuaian visi dan misi prodi yang dipimpinnya. Ia menjelaskan bahwa visi Prodi Hukum Ekonomi Islam adalah terwujudnya insan akademik yang unggul terpercaya, kompetitif, dan mandiri dalam penerapan ekonomi syari'ah. Adapun misinya adalah menyelenggarakan pendidikan dan pengajaran yang berbasis islami, meningkatkan mutu pembelajaran bidang hukum ekonomi syari'ah dengan berpedoman pada kurikulum dan kerangka kerja universitas. Lebih lanjut Muhlis Mappangaja menjelaskan bahwa, berdasarkan visi misi inilah program perkuliahan disusun, tentu di dalam program itu dikembangkan ilmu ekonomi yang berbasis Islam. Menurutnya, selalu ada upaya untuk mengintegrasikan antara ilmu keislaman dan ilmu ekonomi, sehingga melebur menjadi ekonomi Syari'ah. Metode yang digunakan secara formal sekarang adalah model kelas. Namun demikian model kelas ada bingkainya, ada koridornya, yaitu berbasis kurikulum, riset (penelitian), pengabdian, yang langkah-langkahnya berdasar pada nilai-nilai keislaman.

Uraian di atas menunjukkan bahwa integrasi keilmuan merupakan keniscayaan di Unismuh Makassar sebagai sebuah perguruan tinggi yang berciri khas Islam. Terdapat pandangan di kalangan dosen Unismuh bahwa agama Islam adalah basis bagi pengembangan semua ilmu pengetahuan (sains). Disini semua ilmu pengetahuan tidak hanya melebur sebagai bagian dari agama, tetapi menempatkan agama sebagai pendukung seluruh kegiatan ilmiah. Dari pandangan seperti ini dapat disimpulkan bahwa pemikiran tentang integrasi sains dan Islam dewasa ini yang dilakukan oleh kalangan intelektual muslim, tidak lepas dari kesadaran beragama. Mengembangkan pengetahuan yang islami dianggap sebagai implementasi keberagamaan yang totalitas (kaffah) di tengah dunia global yang sarat dengan kemajuan ilmu pengetahuan dan teknologi. Berkembang kesadaran massif di kalangan ilmuan Islam bahwa umat Islam akan maju, dapat menyusul dan menyamai bangsa Barat apabila mampu mentransformasikan dan menyerap secara aktual sains modern dalam rangka memahami wahyu, atau sebaliknya mampu memahami wahyu untuk mengembangkan sains modern.

2. Model Integrasi Ilmu Keislaman dan Sains Modern di Unismuh Makassar 
Selama ini terdapat sekat-sekat yang sangat tajam antara "sains" dan "agama" seolah keduanya menjadi entitas yang berdiri sendiri dan tidak bisa dipertemukan. Sains dan agama dianggap mempunyai wilayah sendiri, baik dari segi objek formal-material, metode penelitian, kriteria kebenaran, peran yang dimainkan oleh ilmuwan, hingga institusi penyelenggaranya. Oleh karena itu tawaran paradigma integrasi keilmuan Islam dan sains dimaksudkan untuk mencari titik temu antara keduanya. Uraian berikut ini berusaha untuk mendalami dan memaparkan lebih jauh bagaimana paradigma integratif ini diterapkan di lingkungan Unismuh Makassar.

Samsul Rizal menjelaskan bahwa paradigma dan model pengintegrasian ilmu di Fakultas Ekonomi dan Bisnis, khususnya di Prodi Ekonomi Islam belum ada model yang paten, tetapi semua mata kuliah harus terintegrasi dengan keislaman. Cara yang ditempuh adalah mengaitkan nilai-nilai Islam yang terdapat dalam al-Qur'an dan alSunnah dengan teori ekonomi.

Pandangan Samsul Rizal dikonfirmasi oleh Agus Salim Harrang bahwa model yang dikembangkan dalam pengintegrasian ilmu adalah sesuai dengan nomenklatur "ekonomi Islam" yang berarti ilmu ekonomi konvensional dipadukan dengan ilmu ekonomi berbasis Islam. Adapun lingkup kajiannya adalah (a) pengembangan teori dan (b) aplikasi. Lingkup pengembangan teori yang dimaksud adalah teori-teori ekonomi konvensional dipelajari secara apa adanya teori itu, setelah selesai dipelajari kemudian dikomparasikan dan disintesiskan dengan teori ekonomi Islam. Agus Salim Harrang memberi kata kunci bahwa apapun model integrasi yang diterapkan tagret utamanya adalah memiliki ilmu dan keterampilan yang dilandasi nilai-nilai keislaman.

Pada aplikasinya, pengintegrasian ilmu melalui materi perkuliahan, secara spesifik belum seluruhnya, namun menurut Samsul Rizal, ada beberapa mata kuliah yang dialihkan ke syariah, antara lain: (a) Etika dan Bisnis beralih menjadi Etika Bisnis Syari'ah; (b) Perbankan beralih menjadi Perbankan Syari'ah; (c) Keuangan beralih menjadi Keuangan Syari'ah. Lebih lanjut Samsul Rizal menjelaskan, pengintegrasian nilai keislaman melalui aktivitas perkuliahan, yaitu: (a) Memulai perkuliahan dengan membaca al Qur'an (mengaji). (b) Memisahkan tempat duduk laki-laki dan perempuan. (c) Mendisiplikan pakaiannya, terutama mahasiswi dianjurkan berbusana sesuai dengan syari'ah.

Ali Hakka (dosen AIK Febis) mengemukakan contoh pengintegrasian ilmu keislaman dan ilmu ekonomi dalam materi perkuliahan, seperti: (a) jual beli, transaksinya menurut ajaran Islam, (b) pelaku bisnis harus islami, (c) memahamkan kepada mahasiswa tentang halal dan haram menurut Islam, dan (d) manajemennya yang 
islami. Ilmu tidak bisa dikotomi, semuanya memiliki kepentingan dalam Islam dan seharusnya senantiasa menjadikan Islam sebagai patokan. Setiap aktivitas di Fak. Ekonomi dan Bisnis baik itu pimpinan. dosen, mahasiswa dan karyawan harus senantiasa berdasarkan pada pedoman hidup dan cita-cita hidup warga Muhammadiyah.

Pengintegrasian ilmu keislaman pada perkuliahan di Fakultas Kedokteran, sebagaimana dikemukakan Irwan Ashari, ditempuh dengan cara setiap mata kuliah atau blok yang berjalan harus berdasarkan al-Islam Kemuhammadiyahan. Mengenai hal ini, telah ada buku panduan di fakultas kedokteran berupa standar karakter dan kompetensi dokter Muhammadiyah, yang penyusunannya melibatkan dosen al-Islam Kemuhammadiyahan. Selain itu, pada peyusunan skripsi harus ada bab tertentu yang memuat tentang alIslam Kemuhammadiyahan. Hal yang sama berlaku pada kegiatan tutorial, seminar, dan diskusi harus senantiasa mengacu dan memuat tentang nilainilai keislaman.

Pengintegrasian ilmu keislaman dalam aktivitas perkuliahan, yaitu: memulai perkuliahan dengan membaca al-Qur'an dan bahasa yang digunakan senantiasa mengacu pada nilai keislaman. Selain itu, ada pula kegiatan ekstrakurikuler di Fakultas Kedokteran, yaitu mahasiswa baru diasramakan (dipesantrenkan) selama satu tahun untuk menanamkan nilai- nilai keislaman pada seluruh mahasiswa kedokteran.

Muhlis Mappangaja mengemukakan bahwa materi kuliah di prodi ekonomi syari'ah semuanya sudah terintegrasi dengan ilmu keislaman. Materi kuliah kalau dikaitkan dengan sains semata, muatannya teori konvensional tidak berdasarkan wahyu al-Qur'an, akan tetapi berasal dari landasan teori yang diperoleh dari percobaan dan pengalaman empiris, sehingga pada tempat-tempat tertentu berbeda antara ekonomi konvensional dengan ekonomi syari'ah. Buktinya dalam sistem ilmu perbankan, menurut ekonomi konvensional riba dianggap sebagai hal yang rasional, sedangkan dalam ekonomi syariah riba adalah perkara yang dilarang.

Berdasarkan uraian di atas, bahwa model integrasi keilmuan yang terjadi di Unismuh Makassar masih pada tahap yang sangat sederhana dan masih tahap mencari bentuk yang ideal. Diskusi tentang paradigma integrasi keilmuan pada level ontologi, epistemologi, dan aksiologi masih harus diintensifkan.

Secara ideal, integrasi ilmu dan agama tidak dapat dilakukan hanya dengan memberikan justifikasi ayat alQur'an pada setiap penemuan ilmu. Integrasi keilmuan bukan sekadar memberikan label Islam pada istilahistilah keilmuan dan sejenisnya, tetapi perlu ada perubahan paradigma pada basis keilmuan Barat, agar sesuai dengan basis dan khazanah keilmuan Islam yang berkaitan dengan realitas 
metafisik, religius dan teks suci. Hal ini penting, sebab menurut Naquib al Attas (1988) sebuah ilmu akan tetap bernafas sekuler kalau tidak didasarkan pada basis ontologis atau pandangan dunia (world view) yang bersumber pada tauhid. Begitu juga, sebuah epistemologi akan tetap bersifat 'eksploitatif dan 'merusak' jika tidak didasarkan pada ontologi yang islami. Meski demikian, bangunan ilmu yang telah terintegrasi tidak banyak berarti jika dipegang oleh orang yang tidak bermoral dan tidak bertanggung jawab, maka perlu dibenahi pada aspek aksiologinya.

Kuntowijoyo (2006) menyatakan bahwa inti dari integrasi adalah upaya menyatukan (bukan sekedar menggabungkan) wahyu Tuhan dan temuan pikiran manusia (ilmu-ilmu integralistik), tidak mengucilkan Tuhan (sekularisme) atau mengucilkan manusia (other worldly asceticisme). Model integrasi adalah menjadikan alQur'an dan Sunnah sebagai grand theory pengetahuan, sehingga ayat-ayat qauliyah dan qauniyah dapat dipakai untuk mengontruksi dan mengembangkan sebuah ilmu. Integrasi yang dimaksud di sini adalah berkaitan dengan usaha memadukan keilmuan umum dengan Islam tanpa harus menghilangkan keunikankeunikan antara dua keilmuan tersebut.

3. Faktor Pendukung dan Penghambat Pengintegrasian Ilmu di Unismuh Makassar.
Beberapa faktor yang mendukung pengintegrasian ilmu di Unismuh Makassar, antara lain dikemukakan Samsul Rizal, yaitu: (a) Komitmen dari pimpinan rektorat dan fakultas, (b) Sumber daya manusia, terkhusus dosen AIK. Muhlis Mappangaja menjelaskan hal yang sama bahwa pimpinan yang sangat setuju dengan program pengintegrasian ilmu. Sementara Agus Salim Harrang menjelaskan faktor pendukung berikutnya adalah suasana akademik yang kondusif, sehingga dosen konsentrasi dalam menjelaskan sehingga terbangun integritas pada mahasiswa.

Adapun faktor yang menghambat pengintegrasian ilmu di Unismuh antara lain dikemukakan oleh Samsul Rizal bahwa umumnya dosen belum memadai pemahaman keislaman yang memadai. Selain itu, sebahagian besar mahasiswa berasal dari sekolah umum, sehingga pengintegrasian keislaman dianggap hal yang baru. Pendapat yang sama dikemukakan oleh Irwan Ashari bahwa kendala yang dihadapi dalam pengintegrasian ilmu antara lain: dosen yang mengajar di fakultas kedokteran sebagian berasal dari luar Unismuh dengan latar belakang pendidikan umum, sehingga belum memadai atau menguasai wawasan al-Islam Kemuhammadiyahan. Begitu pun latar belakang mahasiswa, pada umumnya berasal dari sekolah umum dengan pengetahuan agama yang minim. 
Pandangan yang berbeda dikemukakan Ali Hakka bahwa tidak ada kendala yang ditemukan dalam proses integrasi ilmu di Unismuh karena semua dosen dan mahasiswa menyadari bahwa akan pentingnya memadukan ilmu keislaman dan ilmu umum. Pandangan ini tampaknya lebih melihat pada aspek kesadaran civitas akademika Unismuh akan pentingnya integrasi ilmu. Namun dalam pandangan yang luas, Amin Abdullah (2006) memandang, integrasi keilmuan justru dihadang kesulitan, yaitu kesulitan memadukan studi Islam dan umum yang kadang tidak saling akur karena keduanya ingin saling mengalahkan. Oleh karena itu, diperlukan usaha interkoneksitas yang lebih arif dan bijaksana. Interkoneksitas yang dimaksud oleh Amin Abdullah adalah usaha memahami kompleksitas fenomena kehidupan yang dihadapi dan dijalani manusia. Sehingga setiap bangunan keilmuan apapun, baik keilmuan agama, keilmuan sosial, humaniora, maupun kealaman tidak dapat berdiri sendiri, maka dibutuhkan kerjasama, saling tegur sapa, saling membutuhkan, saling koreksi dan saling keterhubungan antara disiplin keilmuan.

\section{KESIMPULAN}

1. Integrasi Islam dan sains dipandang urgen untuk direalisasikan karena ini merupakan bagian dari implementasi visi dan misi Unismuh Makassar sekaligus merupakan konsekuensi logis Unismuh sebagai perguruan tinggi berciri Islam yang mencita-citakan ilmuan yang agamais, intelek-ulama atau ulama-intelek. Integrasi ilmu juga dipersepsi sebagai aplikasi dari doktrin Islam yang menghendaki umatnya memiliki iman dan ilmu, artinya gagasan ini merupakan dorongan dari kesadaran keagamaan.

2. Model integrasi yang diterapkan di Unismuh Makassar belum ada yang baku, bahkan dapat dikatakan masih mencari model yang ideal. Pilihannnya, bisa islamisasi ilmu, ilmuisasi Islam, atau integrasiinterkoneksi. Kalau menggunakan pendekatan islamisasi ilmu, maka terjadi pemilahan dan peleburan antara ilmu umum dengan ilmu agama. Jika ilmuisasi Islam yang dipilih, maka perumusan teori ilmu pengetahuan didasarkan kepada alQur'an, atau menjadikan al-Qur'an sebagai suatu paradigma. Upaya yang dilakukan adalah objektifikasi. Islam dijadikan sebagai suatu ilmu yang objektif, sehingga ajaran Islam yang terkandung dalam al-Qur'an dapat dirasakan oleh seluruh alam (rahmatan lil 'alamin). Sedangkan pendekatan integrasi-interkoneksi lebih bersifat menghargai keilmuan umum yang sudah ada, karena keilmuan umum juga telah memiliki basis epistemologi, ontologi dan aksiologi yang mapan, sambil mencari letak persamaan, baik metode pendekatan (approach) dan 
metode berpikir (procedure) antar keilmuan dan memasukkan nilainilai keilmuan Islam ke dalamnya, sehingga keilmuan umum dan agama dapat saling bekerja sama tanpa saling mengalahkan.

3. Integrasi ilmu di Unismuh Makassar didukung oleh kebijakan pimpinan yang pro pada program ini, selain iklim akademik yang cukup kondusif. Hanya saja masih terkendala pada minimnya kualitas sumber daya dosen yang mumpuni yang dapat mengintegrasikan agama dan sains. Kendala berikutnya adalah masih minimnya diskursus integrasi keilmuan yang mengacu kepada perspektif ontologis, epistemologis dan aksiologis, sehingga langkah-langkah pengintegrasian tidak jelas hendak dimulai dari mana. Kenyataan yang terjadi integrasi dilakukan secara acak pada kurikulum, materi, yang aktivitas perkuliahan. Belum terpola secara sistematis dan terkadang dilakukan berdasarkan improvisasi dosen secara personal.

\section{DAFTAR PUSTAKA}

Abdullah, M. Amin. 2006. Islamic Studies di Perguruan Tinggi: Pendekatan IntegratifInterkonektif. Cet. I; Yogyakarta: Pustaka Pelajar.

Achmadi. 2005. Ideologi Pendidikan Islam: Paradigma Humanisme Teosentris. Cet. I; Yogyakarta: Pustaka Pelajar.
Anshori dan Zaenal Abidin. 2014. "Format Baru Hubungan Sains Modern dan Islam: Studi Integrasi Keilmuan atas UIN Yogyakarta dan Tiga Universitas Islam Swasta sebagai Upaya Membangun Sains Islam Seutuhnya tahun 2007-2013" dalam Profetika: Jurnal Studi Islam, Vol. 15, No. 1.

Arifin, H.M. 2009. Ilmu Pendidikan Islam: Tinjauan Teoretis dan Praktis Berdasarkan Pedekatan Interdisipliner, edisi revisi. Cet. IV; Jakarta: Bumi Aksara.

Arikunto, Suharsimi. 2010. Prosedur Penelitian: Suatu Pendekatan Praktik. Cet XIV; Jakarta: Rineke Cipta.

Assegaf, Abd. Rachman. 2013. Aliran Pemikiran Pendidikan Islam: Hadharah Keilmuan Tokoh Klasik sampai Modern. Cet. II; Jakarta: Rajawali Pers.

Azra, Azyumardi. 2012. Pendidikan Islam: Tradisi dan Modernisasi di Tengah Tantangan Milenium III. Cet. 1; Jakarta: Kencana.

Bakar, Osman. 1997. Classification of Knowledge in Islam: A Study in Islamic Philoshophies of Science, terj. Purwanto, Hierarki Ilmu: Membangun Rangka-Pikir Islamisasi Ilmu menurut al-Farabi, al-Gazali, dan Quthb al-Din al-Syirazi. Cet. I; Bandung: Mizan. 
Capra, Fritjof. 1997. The Tuning Point: Science, Society, and The Rising Culture, terj. Titik Balik Peradaban: Sains, Masyarakat, dan Kebangkitan Kebudayaan. Yogyakarta: Bentang Budaya.

Daulay, Haidar Putra dan Nurgaya Pasa. 2013. Pendidikan Islam dalam Lintasan Sejarah: Kajian dari Zaman Pertumbuhan sampai Kebangkitan. Cet. I; Jakarta: Kencana.

Departemen Agama Republik Indonesia. 2009. Al-Qur'an dan Terjemahnya. Bandung: PT. Sygma Examedia Arkanleema.

Departemen Pendidikan Nasional.

2008. Kamus Besar Bahasa Indonesia, edisi keempat. Cet. I; Jakarta: Gramedia.

Fathani, Hamzah S. 2009. "Pengintegrasian Pembelajaran Umum dan Agama: Studi atas Sistem Pembelajaran di Pesantren Modern Pendidikan Al-Quran IMMIM Putra Makassar". Disertasi, Pascasarjana UIN Alauddin, Makassar.

Hamdan. 2009. Paradigma Baru Pendidikan Muhammadiyah. Cet. I; Yogyakarta: Ar-ruzz Media.

Handrianto, Budi. 2010. Islamisasi Sains: Sebuah Upaya Mengislamkan Sain Barat
Modern. Cet. I; Jakarta: AlKausar.

Haught, John F. 2004. Science and Religion: From Conflict to Conversation, terj. Fransiskus Borgias, Perjumpaan Sains dan Agama: Dari Konflik ke Dialog. Cet. I; Bandung: Mizan.

Khun, Thomas S. 2012. The Structure of Scientific Revolution, terj. Tjun Surjaman, Peran Paradigma dalam Revolusi Sains. Cet. VII; Bandung: PT. Remaja Rosdakarya.

Kuntowijoyo. 2006. Islam sebagai Ilmu: Epistemologi, Metodologi, dan Etika. Yogyakarta: Tiara Wacana.

Mahzar, Armahedi. 2004. Revolusi Integralisme Islam: Merumuskan Paradigma Sains dan Teknologi Islami. Cet. I; Bandung: Mizan.

Makbuloh, Deden. 2011. Pendidikan Agama Islam: Arah Baru Pengembangan Ilmu dan Kepribadian di Perguruan Tinggi. Cet. I; Jakarta: RajaGrafindo Persada.

Mania, Sitti. 2012. Islamisasi Ilmu Pengetahuan dan Implikasinya terhadap Sistem Pendidikan Islam. Cet. I; Makassar: Alauddin University Press. 